\title{
Lipid Production by Yarrowia lipolytica B9 Using Crude Glycerol as Carbon Source
}

\author{
Nazlı Pınar ARSLAN ${ }^{* 1}$, Özden CANLI TAŞAR² \\ ${ }^{1}$ Bingol University, Vocational School of Health Services, Bingöl, Turkey \\ ${ }^{2}$ Erzurum Technical University, High Technology Application and Research Centre, Erzurum, Turkey \\ ORCID ID: Nazlı Pinar ARSLAN: https:/ /orcid.org/0000-0002-3951-4418; Özden CANLI TAŞAR: https://orcid.org/0000-0002-4313-5373
}

\begin{tabular}{llll}
\hline Received: 16.03 .2021 & Accepted: 02.08.2021 & Published online: 01.10.2021 & Issue published: 31.12 .2021 \\
\hline
\end{tabular}

Abstract: The present study was carried out to optimize some culture conditions to increase lipid production from Yarrowia lipolytica B9 in crude glycerol-based medium. The experiments displayed that too high concentrations of ammonium sulfate, $\mathrm{KH}_{2} \mathrm{PO}_{4}$, and $\mathrm{MgSO}_{4}$ increased cell growth but inhibited lipid synthesis. In contrast, more synthesis of lipids was determined to be achived at high concentrations of $\mathrm{NaCl}$. The optimum concentrations of glycerol, ammonium sulfate, $\mathrm{KH}_{2} \mathrm{PO}_{4}, \mathrm{MgSO}_{4}$, and $\mathrm{NaCl}$ for lipid synthesis were determined as 50,3, 1.5, 1 and $5 \mathrm{~g} / \mathrm{L}$, respectively. The optimal incubation time for lipid synthesis was found to be 6 days. Lipid concentration of $2.69 \mathrm{~g} / \mathrm{L}$ and lipid content of $60.1 \%$, were reached under optimal culture conditions.

Keywords: Oleaginous, yeast, mineral salt, optimization.

\section{Kaynaklarından Ham Gliserolü Kullanarak Yarrowia lipolytica B9 ile Lipit Üretimi}

\begin{abstract}
Öz: Mevcut çalışma, ham gliserol bazlı besiyerinde Yarrowia lipolytica B9'dan lipit üretimini artırmak için bazı kültür koşullarını optimize etmek amacıyla gerçekleştirilmiştir. İnceleme sonucunda amonyum sülfat, $\mathrm{KH}_{2} \mathrm{PO}_{4}$ ve $\mathrm{MgSO}_{4}{ }^{\prime}$ ün çok yüksek konsantrasyonlarının hücre büyümesini artırdığı fakat lipit sentezini inhibe ettiği gözlemlendi. Buna ek olarak, daha fazla lipit sentezinin yüksek $\mathrm{NaCl}$ konsantrasyonlarında başarıldığı ortaya çıtı. Lipit sentezi için gliserol, amonyum sülfat, $\mathrm{KH}_{2} \mathrm{PO}_{4}, \mathrm{MgSO}_{4}$ ve NaCl'nin optimum konsantrasyonları sırasıyla 50; 3; 1,5; 1 ve 5 gr/lt olarak belirlendi. Lipid sentezi için optimal inkübasyon süresinin 6 gün olduğu bulundu. Optimal kültür koşullarında 2.69 gr/lt lipit konsantrasyonuna ve \%60.1 lipit içeriğine ulaşıldı.
\end{abstract}

Anahtar kelimeler: Yağlı, maya, mineral tuz, optimizasyon.

\section{Introduction}

Today, microorganisms are used in the production of various substances such as single cell protein, enzyme, recombinant protein, antibiotics, ethanol, glutathione, pigments, organic acids, and polysaccharides. In addition to these valuable products, microorganisms have recently been used in the production of biolipids which are also called single cell oils (Fakas et al., 2009).

The term "oleaginous" is extensively used for microorganisms accumulating lipids over $20 \%$ on dry weight basis. Some genera of microalgae, yeasts, molds, and bacteria show oleaginous property; however, most of oleaginous microorganisms belong to the yeast genera such as Candida, Cryptococcus, Rhodotorula, Lipomyces, and Yarrowia (Taskin et al., 2015; Ortucu et al., 2017). For instance, many investigators have documented that strains of Yarrowia lipolytica are good lipid producers (Gao et al., 2017; Dobrowolski et al., 2019).

It has been well documented that some nutritional and environmental culture conditions significantly trigger lipid synthesis in oleaginous yeasts, thereby causing the lipid accumulation over $70 \%$ on dry weight basis (Beopoulos et al., 2009; Taskin et al., 2016). For example, low amounts of nitrogen and phosphorus sources but high amounts of carbon sources increase lipogenesis in oleaginous yeasts (Amaretti et al., 2010; Taskin et al., 2016; Wang et al., 2018).

The industrial production of biodiesel is mainly performed from vegetable oils. Recently, lipids of oleaginous microorganisms have also been reported to be used as alternative biodiesel feedstock. However, high cost of carbon sources which are employed for cultivation of oleaginous microorganisms significantly limits economical production of microbial lipids (Meng et al., 2009; Santek et al., 2018). To solve this problem, cheap agricultural byproducts and organic wastes such as molasses, whey, glycerol, and fruit peels have been suggested to be utilized as alternative carbon sources in the production of microbial lipids (Papanikolaou et al., 2007; Fakas et al., 2009; Meng et at., 2009).

Glycerol is a by-product that is released from vegetable and animal oils during the production of biodiesel. It is stated that an average $1 \mathrm{~kg}$ of glycerol is produced during the production of per $10 \mathrm{~kg}$ biodiesel. Therefore, it is produced in high amounts every year by the biodiesel industry (Papanikolaou \& Aggelis, 2010; Anand \& Saxena, 2011). In addition to 60-90\% glycerol, crude glycerol contains water, methanol, mineral elements, and fatty acids. Although crude glycerol is produced in large quantities, it is not of much medical and industrial importance (Swiatkiewicz \& Koreleski, 2009; 
Chen \& Walker, 2011; Yang et al., 2012). As an alternative approach, crude glycerol is employed as a carbon source for production of various microbial substances today. For example, many studies have demonstrated that this substance is effectively employed as a carbon source in synthesis of lipids from various yeasts, including $Y$. lipolytica strains (André et al., 2009; Gao et al., 2016; Kumar et al., 2020). Accordingly, this work was conducted to produce lipids from $Y$. lipolytica B9 in crude glycerol-based medium and to optimize some culture conditions for enhancement of lipid production.

\section{Material and Methods}

\subsection{Chemicals and microorganism}

Chloroform, methanol, $\mathrm{HCl}$, and mineral salts were purchased from Sigma (USA) but potato dextrose agar (PDA) and potato dextrose broth (PDB) from Merck (Germany). The strain Yarrowia lipolytica B9 (Taskin et al., 2015) was selected as the test microorganism for lipid production in glycerol-based medium.

\subsection{Preparation of yeast preculture}

The yeast was firstly activated on PDA medium at $15^{\circ} \mathrm{C}$ for $48 \mathrm{~h}$. Then, one loopful of the yeast biomass on PDA was inoculated into $250 \mathrm{~mL}$ flask containing $100 \mathrm{~mL}$ of PDB medium. After the flask was placed into shaking incubator, it was incubated at $15^{\circ} \mathrm{C}$ and $200 \mathrm{rpm}$ for $48 \mathrm{~h}$. The prepared preculture was then used for the inoculation of glycerol-based production medium described below.

\subsection{Lipid production in glycerol-based medium}

Experiments for production of lipids from Y. lipolytica B9 were performed in $250 \mathrm{~mL}$ flasks containing $100 \mathrm{~mL}$ of the production medium that was composed crude glycerol, ammonium sulfate, $0.5 \mathrm{~g} / \mathrm{L} \mathrm{KH}_{2} \mathrm{PO}_{4}$, and $0.5 \mathrm{~g} / \mathrm{L} \mathrm{MgSO}_{4}$ ( $\mathrm{pH}$ 6.0). The initial experiments were focused on determining the most favorable concentrations of glycerol (20-60 g/L) and ammonium sulfate (2-5 g/L) for lipid synthesis. After determining the most favorable concentrations of glycerol and ammonium sulfate, the effects of different concentrations of $\mathrm{KH}_{2} \mathrm{PO}_{4}(0.5-2.5 \mathrm{~g} / \mathrm{L})$, $\mathrm{MgSO}_{4}(0.5-2.5 \mathrm{~g} / \mathrm{L})$, and $\mathrm{NaCl}(0-6 \mathrm{~g} / \mathrm{L})$ on yeast growth and lipid synthesis were examined. Final experiments were done to elucidate the influence of incubation time (up to 7 days) on lipid synthesis and cell growth. During the optimization experiments, the flasks were inoculated with $2 \mathrm{~mL}$ of preculture $\left(\mathrm{OD}_{600}=2.0\right)$ and they were incubated at $15^{\circ} \mathrm{C}$ and $200 \mathrm{rpm}$.

\subsection{Analysis of lipid production and cell growth}

At the end of the specified incubation time, the yeast cultures were centrifuged at $5000 \mathrm{rpm}$ for $10 \mathrm{~min}$. The supernatant was removed and the precipitated wet cells were dried to constant weight at $70^{\circ} \mathrm{C}$. Final weight of dried cells was termed as cell concentration $(\mathrm{g} / \mathrm{L})$. Yeast lipids were extracted from dry cells with chloroformmethanol treatment. For this purpose, dried cells $(0.1 \mathrm{~g})$ were firstly hydrolyzed with $10 \mathrm{~mL}$ of $4 \mathrm{~N} \mathrm{HCl}$ at $60^{\circ} \mathrm{C}$ for $2 \mathrm{~h}$ in a water bath. The prepared suspension was centrifuged at $5000 \mathrm{rpm}$ for $10 \mathrm{~min}$ and the supernatant was discharged (Tasselli et al., 2018). Then, the precipitated cells in the tube were extracted with $5 \mathrm{~mL}$ of chloroform-methanol mixture $(2 \mathrm{~V} \backslash \mathrm{V})$. After the suspension was vortexed for $5 \mathrm{~min}$, it was centrifuged at
$5000 \mathrm{rpm}$ for $5 \mathrm{~min}$. Afterwards, the supernatant was discharged and $5 \mathrm{~mL}$ of chloroform-methanol mixture was re-added into the tube. After chloroform-methanol extraction and centrifugation were applied four cycles, the precipitated wet cells in tubes were dried to constant weight at $70^{\circ} \mathrm{C}$. After the final weight of dried cells was subtracted from their initial weight, and the decrease in dry weight was expressed as lipid concentration $(\mathrm{g} / \mathrm{L})$. Lipid content was determined according to the following formula. Lipid content $(\%)=[$ lipid concentration $(\mathrm{g} / \mathrm{L}) /$ cell biomass $(\mathrm{g} / \mathrm{L})] \times 100$.

\subsection{Statistical analysis}

Each analysis was performed in three biological and two technical replicates. All the measurements were mean \pm standard deviation $( \pm S D)$ of six determinations $(n=6)$. Statistical difference was analyzed in the SPSS 15.0 package program using $\mathrm{P}<0.05$ significance level one-way ANOVA.

\section{Results}

\subsection{Influence of ammonium sulfate and crude glycerol concentrations on lipid production}

Different concentrations of ammonium sulfate and crude glycerol were tested for enhancement of lipid synthesis in the yeast.

As seen from Table 1, increasing concentrations of ammonium sulfate resulted in a continuous increase in cell biomass. For example, even at the lowest and highest concentrations of glycerol, the maximum cell biomass was measured at a concentration of $5 \mathrm{~g} / \mathrm{L}$ of ammonium sulfate. On the contrary, excessive concentrations of ammonium sulfate decreased lipid production. For example, when glycerol concentration was kept constant at $20 \mathrm{~g} / \mathrm{L}$, maximum lipid synthesis was detected in the presence of $2 \mathrm{~g} / \mathrm{L}$ ammonium sulfate and higher concentrations of ammonium sulfate decreased lipid synthesis. It was found that crude glycerol concentrations up to $50 \mathrm{~g} / \mathrm{L}$ increased both cell growth and lipid synthesis. When the production medium contained $50 \mathrm{~g} / \mathrm{L}$ glycerol, the maximum lipid concentration $(1.55 \mathrm{~g} / \mathrm{L})$ and lipid content ( $36.4 \%)$ were accomplished at an ammonium sulfate concentration of $3 \mathrm{~g} / \mathrm{L}$. On the other hand, it was observed that when crude glycerol concentration was increased to $60 \mathrm{~g} / \mathrm{L}$, both lipid synthesis and cell growth slightly reduced. Therefore, subsequent experiments were performed in the culture medium containing $50 \mathrm{~g} / \mathrm{L}$ glycerol and $3 \mathrm{~g} / \mathrm{L}$ ammonium sulfate.

Table 1. Effect of glycerol and ammonium sulfate concentrations on cell growth and lipid synthesis in Yarrowia lipolytica B9

\begin{tabular}{lllll}
\hline $\begin{array}{l}\text { Crude } \\
\text { glycerol } \\
(\mathrm{g} / \mathrm{L})\end{array}$ & $\begin{array}{l}\text { Ammonium } \\
\text { sulfate }(\mathrm{g} / \mathrm{L})\end{array}$ & $\begin{array}{l}\text { Cell } \\
(\mathrm{g} / \mathrm{L})\end{array}$ & $\begin{array}{l}\text { Lipid } \\
\text { concentration } \\
(\mathrm{g} / \mathrm{L})\end{array}$ & $\begin{array}{l}\text { Lipid } \\
\text { content } \\
(\%)\end{array}$ \\
\hline 20 & 2 & $3.22 \pm 0.07 \mathrm{e}$ & $0.86 \pm 0.03 \mathrm{fg}$ & 26.7 \\
& 3 & $3.31 \pm 0.09 \mathrm{de}$ & $0.82 \pm 0.04 \mathrm{~h} 1$ & 24.7 \\
& 4 & $3.41 \pm 0.07 \mathrm{~d}$ & $0.78 \pm 0.04 \mathrm{~h} 1$ & 22.8 \\
& 5 & $3.56 \pm 0.08 \mathrm{~cd}$ & $0.74 \pm 0.021$ & 20.7 \\
30 & 2 & $3.43 \pm 0.1 \mathrm{~d}$ & $0.99 \pm 0.05 \mathrm{e}$ & 28.9 \\
& 3 & $3.57 \pm 0.1 \mathrm{~cd}$ & $0.96 \pm 0.03 \mathrm{e}$ & 26.9 \\
& 4 & $3.71 \pm 0.12 \mathrm{c}$ & $0.92 \pm 0.03 \mathrm{fg}$ & 24.8 \\
& 5 & $3.93 \pm 0.11 \mathrm{bc}$ & $0.82 \pm 0.05 \mathrm{~h} 1$ & 20.9 \\
\hline
\end{tabular}




\begin{tabular}{lllll}
\hline $\begin{array}{l}\text { Crude } \\
\text { glycerol } \\
(\mathrm{g} / \mathrm{L})\end{array}$ & $\begin{array}{l}\text { Ammonium } \\
\text { sulfate }(\mathrm{g} / \mathrm{L})\end{array}$ & $\begin{array}{l}\text { Cell mass } \\
(\mathrm{g} / \mathrm{L})\end{array}$ & $\begin{array}{l}\text { Lipid } \\
\text { concentration } \\
(\mathrm{g} / \mathrm{L})\end{array}$ & $\begin{array}{l}\text { Lipid } \\
\text { content } \\
(\%)\end{array}$ \\
\hline 40 & 2 & $3.72 \pm 0.15 \mathrm{c}$ & $1.15 \pm 0.03 \mathrm{~d}$ & 30.9 \\
& 3 & $3.89 \pm 0.14 \mathrm{bc}$ & $1.25 \pm 0.04 \mathrm{c}$ & 32.1 \\
& 4 & $4.11 \pm 0.14 \mathrm{bc}$ & $1.11 \pm 0.04 \mathrm{~d}$ & 27.0 \\
& 5 & $4.23 \pm 0.13 \mathrm{~b}$ & $0.98 \pm 0.05 \mathrm{e}$ & 23.2 \\
50 & 2 & $3.98 \pm 0.1 \mathrm{bc}$ & $1.35 \pm 0.06 \mathrm{bc}$ & 33.9 \\
& 3 & $4.25 \pm 0.1 \mathrm{~b}$ & $1.55 \pm 0.08 \mathrm{a}$ & 36.4 \\
& 4 & $4.56 \pm 0.12 \mathrm{a}$ & $1.45 \pm 0.05 \mathrm{~b}$ & 31.8 \\
& 5 & $4.72 \pm 0.17 \mathrm{a}$ & $1.33 \pm 0.08 \mathrm{bc}$ & 28.2 \\
& 2 & $3.81 \pm 0.09 \mathrm{c}$ & $1.25 \pm 0.06 \mathrm{c}$ & 32.8 \\
& 3 & $4.05 \pm 0.1 \mathrm{bc}$ & $1.37 \pm 0.06 \mathrm{bc}$ & 33.8 \\
& 4 & $4.22 \pm 0.11 \mathrm{~b}$ & $1.42 \pm 0.06 \mathrm{~b}$ & 33.6 \\
& 5 & $4.03 \pm 0.13 \mathrm{bc}$ & $1.19 \pm 0.03 \mathrm{~cd}$ & 29.5 \\
& & & &
\end{tabular}

3.2. Influence of $\mathrm{MgSO}_{4}, \quad \mathrm{KH}_{2} \mathrm{PO}_{4}$ and $\mathrm{NaCl}$ concentrations on cell growth and lipid synthesis in Yarrowia lipolytica B9

When experiments were carried out at optimal concentrations of glycerol and ammonium sulfate, maximum values for lipid concentration $(1.79 \mathrm{~g} / \mathrm{L})$ and lipit content $(40.9 \%)$ were -reached in the medium containing $1 \mathrm{~g} / \mathrm{L}$ magnesium sulfate, but higher concentrations of magnesium sulfate gradually reduced lipid synthesis. For example, the highest concentration (2.5 $\mathrm{g} / \mathrm{L}$ ) of magnesium sulfate gave rise to the lowest lipid concentration $(1.36 \mathrm{~g} / \mathrm{L})$. In contrast to lipid synthesis, increasing concentrations of magnesium sulfate caused continuous increases in cell concentration. For instance, the maximum value $(4.72 \mathrm{~g} / \mathrm{L})$ for cell concentration was measured at the highest concentration $(2.5 \mathrm{~g} / \mathrm{L})$ of magnesium sulfate (Fig. 1).

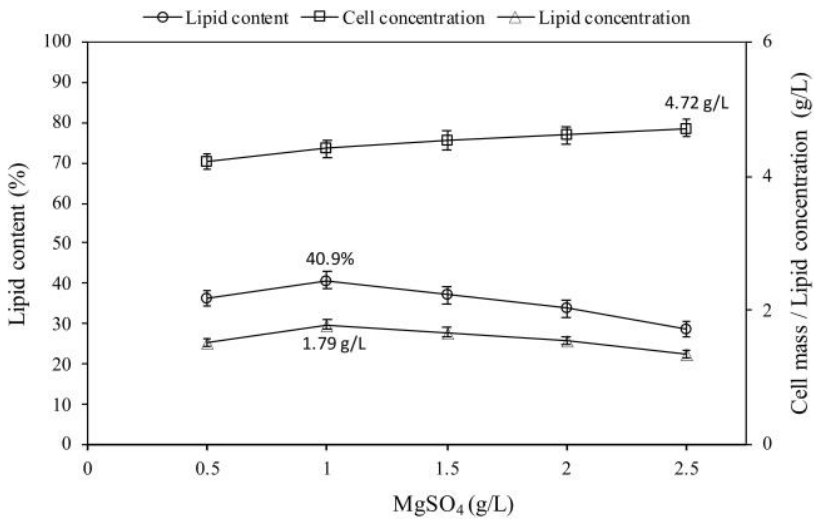

Figure 1. Effect of $\mathrm{MgSO}_{4}$ concentration on cell growth and lipid synthesis in Yarrowia lipolytica B9. Culture conditions: Glycerol 50 $\mathrm{g} / \mathrm{L}$, ammonium sulfate $3 \mathrm{~g} / \mathrm{L}, \mathrm{KH}_{2} \mathrm{PO}_{4} 0.5 \mathrm{~g} / \mathrm{L}$, temperature $15^{\circ} \mathrm{C}$, shaking speed $200 \mathrm{rpm}$, initial $\mathrm{pH} 6.0$ and incubation time 7 days. All the measurements were mean \pm standard deviation $( \pm S D)$ of six determinations $(n=6)$.

Figure 1 shows that the maximum values for both lipid concentration $(2.12 \mathrm{~g} / \mathrm{L})$ and lipid content $(45.9 \%)$ were recorded in the presence of $1.5 \mathrm{~g} / \mathrm{L} \mathrm{KH}_{2} \mathrm{PO}_{4}$, while supplementation of $\mathrm{KH}_{2} \mathrm{PO}_{4}$ over $1.5 \mathrm{~g} / \mathrm{L}$ significantly decreased lipid synthesis. For example, the lowest values for lipid concentration and lipid contents were measured at the highest concentration $(2.5 \mathrm{~g} / \mathrm{L})$ of $\mathrm{KH}_{2} \mathrm{PO}_{4}$. On the contrary, a continuous enhancement in cell concentration occured as $\mathrm{KH}_{2} \mathrm{PO}_{4}$ concentration was increased. For example, the maximum value $(4.81 \mathrm{~g} / \mathrm{L})$ for cell concentration was reached at the highest concentration $(2.5 \mathrm{~g} / \mathrm{L})$ of $\mathrm{KH}_{2} \mathrm{PO}_{4}$ (Fig. 2).

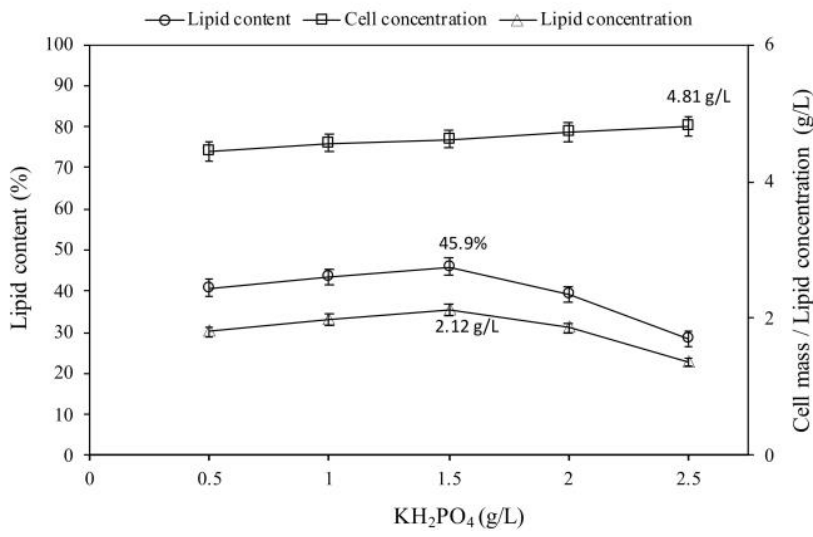

Figure 2. Effect of $\mathrm{KH}_{2} \mathrm{PO}_{4}$ concentration on cell growth and lipid synthesis in Yarrowia lipolytica B9. Culture conditions: Glycerol 50 $\mathrm{g} / \mathrm{L}$, ammonium sulfate $3 \mathrm{~g} / \mathrm{L}, \mathrm{MgSO}_{4} 1 \mathrm{~g} / \mathrm{L}$, temperature $15^{\circ} \mathrm{C}$, shaking speed $200 \mathrm{rpm}$, initial pH 6.0 and incubation time 7 days. All the measurements were mean \pm standard deviation $( \pm S D)$ of six determinations $(n=6)$.

Experiments revealed that in comparison with the control medium (without addition of $\mathrm{NaCl}$ ), the supplementation of $\mathrm{NACl}$ upto $3 \mathrm{~g} / \mathrm{L}$ increased cell concentration. However, $\mathrm{NaCl}$ concentrations over $3 \mathrm{~g} / \mathrm{L}$ caused gradual decreases in cell concentrations. Lipid synthesis increased as $\mathrm{NaCl}$ concentration increased and the maximum values for lipid concentration $(2.68 \mathrm{~g} / \mathrm{L})$ and lipid content $(59.7 \%)$ were obtained at $5 \mathrm{~g} / \mathrm{L} \mathrm{NaCl}$ concentration (Fig. 3). However, $\mathrm{NaCl}$ concentrations above $5 \mathrm{~g} / \mathrm{L}$ were found to reduce lipid synthesis.

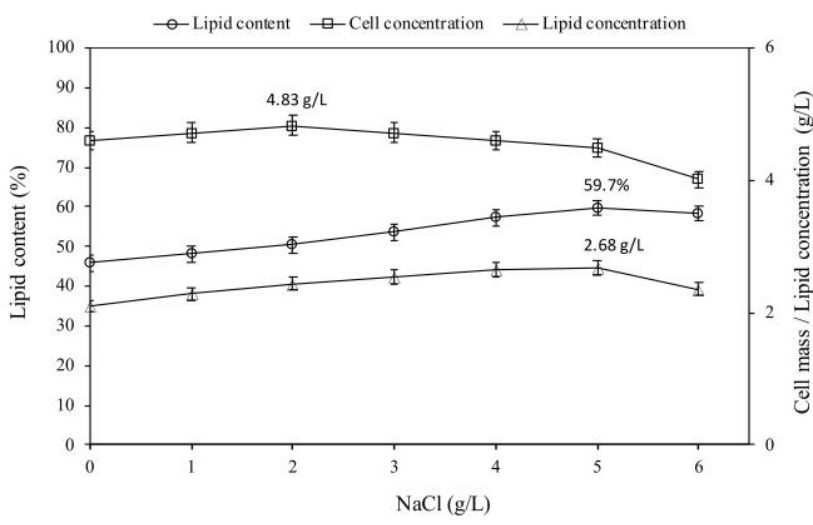

Figure 3. Effect of $\mathrm{NaCl}$ concentration on cell growth and lipid synthesis in Yarrowia lipolytica B9. Culture conditions: Glycerol 50 $\mathrm{g} / \mathrm{L}$, ammonium sulfate $3 \mathrm{~g} / \mathrm{L}, \mathrm{KH}_{2} \mathrm{PO}_{4} 1.5 \mathrm{~g} / \mathrm{L}, \mathrm{MgSO}_{4} 1 \mathrm{~g} / \mathrm{L}$, temperature $15^{\circ} \mathrm{C}$, shaking speed $200 \mathrm{rpm}$, initial $\mathrm{pH} 6.0$ and incubation time 7 days. All the measurements were mean \pm standard deviation $( \pm S D)$ of six determinations $(n=6)$.

As seen from Figure 4, the yeast cells showed the best growth performance in the first three days (especially in the first day) of incubation. The cell concentration reached to maximum value $(4.48 \mathrm{~g} / \mathrm{L})$ on day 4 and no increase was detected in the following days. Unlike cell growth, no significant lipid accumulation was detected within the first three days and an important increment in lipid synthesis was observed after day 3 . Both lipid concentration and lipid content reached to maximum values (respectively $2.69 \mathrm{~g} / \mathrm{L}$ and $60.1 \%$ ) at the end of day 6. On the other hand, 
both lipid concentration and lipid content showed a small reduction when incubation time was increased from 6 to 7 days (Fig. 4).

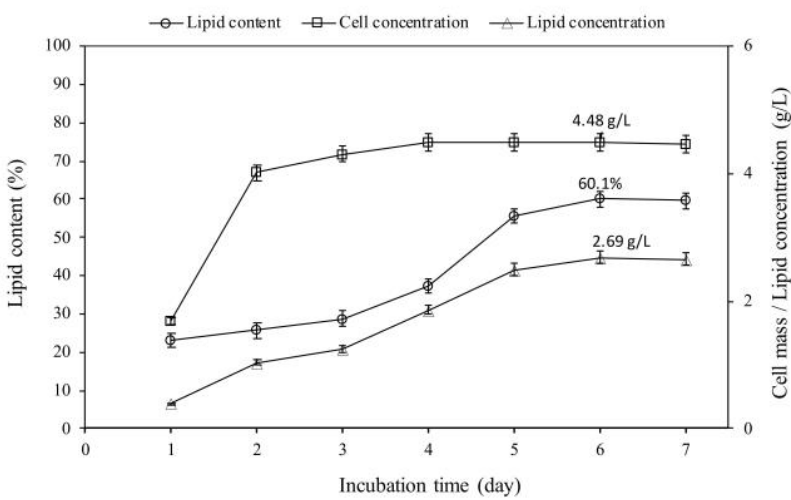

Figure 4. Effect of incubation time on cell growth and lipid synthesis in Yarrowia lipolytica B9. Culture conditions: Glycerol 50 $\mathrm{g} / \mathrm{L}$, ammonium sulfate $3 \mathrm{~g} / \mathrm{L}, \mathrm{KH}_{2} \mathrm{PO}_{4} 1.5 \mathrm{~g} / \mathrm{L}, \mathrm{MgSO}_{4} 1 \mathrm{~g} / \mathrm{L}$, temperature $15^{\circ} \mathrm{C}$, shaking speed $200 \mathrm{rpm}$ and initial $\mathrm{pH}$ 6.0. All the measurements were mean \pm standard deviation $( \pm \mathrm{SD})$ of six determinations $(n=6)$.

\section{Discussion}

It is well known that Yarrowia lipolytica strains utilize glycerol as a cheap carbon source for lipid synthesis. Therefore, in this work, crude glycerol was selected as a carbon source for lipid production. In order to increase lipid synthesis, different concentrations of carbon (crude glycerol) and nitrogen (ammonium sulfate) sources were tested primarily. It was determined that low concentrations of ammonium sulfate and high concentrations of glycerol, in other words, nitrogenlimited but carbon excess conditions increased the lipid synthesis in the yeast. This result was similar to those of previous studies (Taskin et al., 2015; Ortucu et al., 2017; Zhang et al., 2019).

The present study revealed that excessive concentrations of $\mathrm{MgSO}_{4}$ and $\mathrm{KH}_{2} \mathrm{PO}_{4}$ increased cell growth but decreased lipid synthesis. This was mainly attributed to the presence of $\mathrm{P}$ and $\mathrm{S}$ in these mineral salts. Because, in the literature, it is stated that carbon source is directed to cell growth in the presence of excessive $\mathrm{P}$ and $S$ but to lipid synthesis under $\mathrm{P}$ and $\mathrm{S}$ limited conditions (Bandhu et al., 2014; González-García et al., 2017; Ortucu et al., 2017; Elfeky et al., 2019). The experiments revealed that $\mathrm{NaCl}$ concentrations up to $5 \mathrm{~g} / \mathrm{L}$ significantly stimulated lipid synthesis. This finding is consistent with the fact that $\mathrm{NaCl}$ increases lipid accumulation by causing stress in yeasts (Tchakouteu et al., 2017; Guo et al., 2019).

The experiments showed that although cell growth stopped at the end of day 3 , lipid synthesis continued until the end of day 6 . The result is in parallel with the knowledge that extended incubation times are more favorable for lipid synthesis in oleaginous microorganisms (Ortucu et al., 2017; Abghari \& Chen, 2017; Radha et al., 2020; Altun et al., 2020). A small decrease in lipid concentration was observed after day 6 . This decrease can be explained by depletion of carbon source (glycerol) in the culture medium. Namely, storage lipids might have been used as carbon source by the yeast since glycerol was exhausted in the medium. The lipid content of the yeast was determined to be $60.1 \%$ under optimized culture conditions. This value was higher than the lipid contents of other $Y$. lipolytica strains which were cultivated in glycerol-based medium in the previous studies (Sriwongchai et al., 2013; Rakicka et al., 2015; Sara et al., 2016; Gajdoš et al., 2017; Niehus et al., 2018). Furthermore, it was higher than lipid contents of other oleaginous yeasts in the previous studies (Karatay \& Donmez, 2010; Amaretti et al., 2010; Gao et al., 2017; Uprety et al., 2017). Taskin et al. (2015) informed that lipids of Y. lipolytica B9 included oleic acid, cis-10-heptadecenoic acid, palmitoleic acid, and palmitic acid but not polyunsaturated fatty acids and therefore could be used as a biodiesel feedstock. It was shown in the current work that lipids of this yeast could be produced using crude glycerol as a cheap carbon source. Since crude glycerol is a waste material that does not find much use today, it is thought that performing lipid production using crude glycerol can contribute to reducing the environmental pollution problem as well as cost of biodisel feedstock.

Ethics committee approval: Ethics committee approval is not required for this study.

Conflict of interest: The authors declare that there is no conflict of interest.

\section{References}

Abghari, A., \& Chen, S. (2017). Engineering Yarrowia lipolytica for enhanced production of lipid and citric acid. Fermentation, 3(3), 34. https://doi.org/10.3390/fermentation3030034

Altun, R., Esim, N., Aykutoglu, G., Baltaci, M.O., Adiguzel, A., \& Taskin, M. (2020). Production of linoleic acid-rich lipids in molasses-based medium by oleaginous fungus Galactomyces geotrichum TS61. Journal of Food Processing and Preservation, 44(7), e14518. https://doi.org/10.1111/jfpp.14518

Amaretti, A., Raimondi, S., Sala, M., Roncaglia, L., De Lucia, M., Leonardi, A., \& Rossi, M. (2010). Single cell oils of the cold-adapted oleaginous yeast Rhodotorula glacialis DBVPG 4785. Microbial cell factories, 9(1), 1-6. https://doi.org/10.1186/1475-2859-9-73

Anand, P., \& Saxena, R.K. (2011). A comparative study of solvent-assisted pretreatment of biodiesel derived crude glycerol on growth and 1,3propanediol production from Citrobacter freundi. New Biotechnology, 00, 1-7. https://doi.org/10.1016/i.nbt.2011.05.010

André, A., Chatzifragkou, A., Diamantopoulou, P., Sarris, D., Philippoussis, A., Galiotou-Panayotou, M., ... \& Papanikolaou, S. (2009). Biotechnological conversions of bio-diesel-derived crude glycerol by Yarrowia lipolytica strains. Engineering in Life Sciences, 9(6), 468-478. https://doi.org/10.1002/elsc.200900063

Bandhu, S., Dasgupta, D., Akhter, J., Kanaujia, P., Suman, S.K., Agrawal, D., ... \& Ghosh, D. (2014). Statistical design and optimization of single cell oil production from sugarcane bagasse hydrolysate by an oleaginous yeast Rhodotorula sp. IIP-33 using response surface methodology. SpringerPlus, 3(1), 1-11. https://doi.org/10.1186/21931801-3-691

Beopoulos, A., Cescut, J., Haddouche, R., Uribelarrea, J.L., Molina-Jouve, C., \& Nicaud, J.M. (2009). Yarrowia lipolytica as a model for bio-oil production. Progress in lipid research, 48(6), 375-387. https://doi.org/10.1016/j.plipres.2009.08.005

Chen, Y.H., \& Walker, T.H. (2011). Biomass and lipid production of heterotrophic microalgae Chlorella protothecoides by using biodieselderived crude glycerol. Biotechnology Letters, 33, 1973-1983. https://doi.org/10.1007/s10529-011-0672-y

Dobrowolski, A., Drzymała, K., Rzechonek, D.A., Mituła, P., \& Mirończuk, A.M. (2019). Lipid production from waste materials in seawater-based medium by the yeast Yarrowia lipolytica. Frontiers in Microbiology, 10, 547. https://doi.org/10.3389/fmicb.2019.00547

Elfeky, N., Elmahmoudy, M., Zhang, Y., Guo, J., \& Bao, Y. (2019). Lipid and carotenoid production by Rhodotorula glutinis with a combined cultivation mode of nitrogen, sulfur, and aluminium stress. Applied Sciences, 9(12), 2444. https://doi.org/10.3390/app9122444

Fakas, S., Papanikolaou, S., Batsos, A., Galiotou-Panayotou, M., Mallouchos, A., \& Aggelis, G. (2009). Evaluating renewable carbon sources as substrates for single cell oil production by Cunninghamella 
echinulata and Mortierella isabellina, Biomass and Bioenergy, 33, 573-580. https://doi.org/10.1016/j.biombioe.2008.09.006

Gao, Z., Ma, Y., Wang, Q., Zhang, M., Wang, J., \& Liu, Y. (2016). Effect of crude glycerol impurities on lipid preparation by Rhodosporidium toruloides yeast 32489. Bioresource technology, 218, 373-379. https://doi.org/10.1016/j.biortech.2016.06.088

Gao, R., Li, Z., Zhou, X., Cheng, S., \& Zheng, L. (2017). Oleaginous yeast Yarrowia lipolytica culture with synthetic and food waste-derived volatile fatty acids for lipid production. Biotechnology for biofuels, 10(1), 1-15. https:// doi.org/10.1186/s13068-017-0942-6

Gajdoš, P., Nicaud, J.M., \& Čertík, M. (2017). Glycerol conversion into a single cell oil by engineered Yarrowia lipolytica. Engineering in Life Sciences, 17(3), 325-332. https:/ / dx.doi.org/10.1002\%2Felsc.201600065

González-García, Y., Rábago-Panduro, L.M., French, T., CamachoCórdova, D.I., Gutiérrez-González, P., \& Córdova, J. (2017). High lipids accumulation in Rhodosporidium toruloides by applying single and multiple nutrients limitation in a simple chemically defined medium. Annals of Microbiology, 67(8), 519-527. https://doi.org/10.1007/s13213$\underline{017-1282-2}$

Guo, Y., Xie, S., Yuan, J.S., \& Kao, K.C. (2019). Effects of seawater on carotenoid production and lipid content of engineered Saccharomyces Fermentation,

$5(1)$

https://doi.org/10.3390/fermentation5010006

Karatay, S.E., \& Dönmez, G. (2010). Improving the lipid accumulation properties of the yeast cells for biodiesel production using molasses. $\begin{array}{llll}\text { Bioresource Technology, 101(20), 7988-7990. } & \end{array}$ https://doi.org/10.1016/j.biortech.2010.05.054

Kumar, L.R., Yellapu, S.K., Tyagi, R.D., \& Drogui, P. (2020). Purified crude glycerol by acid treatment allows to improve lipid productivity by Yarrowia lipolytica SKY7. Process Biochemistry, 96, 165-173. https://doi.org/10.1016/i.procbio.2020.06.010

Meng, X., Yang, J., Xu, X., Zhang, L., Nie, Q., \& Xian, M. (2009). Biodiesel production from oleaginous microorganisms. Renewable energy, 34(1), 15. https:// doi.org/10.1016/B978-0-12-816856-1.00027-0

Niehus, X., Casas-Godoy, L., Rodríguez-Valadez, F.J., \& Sandoval, G. (2018). Evaluation of Yarrowia lipolytica oil for biodiesel production: land use oil yield, carbon, and energy balance. Journal of Lipids. https://doi.org/10.1155/2018/6393749

Ortucu, S., Yazici, A., Taskin, M., \& Cebi, K. (2017). Evaluation of waste loquat kernels as substrate for lipid production by Rhodotorula glutinis SO28. Waste and biomass valorization, 8(3), 803-810. https:// doi.org/10.1007/s12649-016-9615-0

Papanikolaou, S., \& Aggelis, G. (2010). Yarrowia lipolytica: A model microorganism used for the production of tailor-made lipids. European Journal of Lipid Science and Technology, 112(6), 639-654. https://doi.org/10.1002/ejlt.200900197

Papanikolaou, S., Galiotou-Panayotou, M., Fakas, S., Komaitis, M., \& Aggelis, G. (2007). Lipid production by oleaginous Mucorales cultivated on renewable carbon sources. European Journal of Lipid Science and Technology, 109(11), 1060-1070. https://doi.org/10.1002/ejlt.200700169

Rakicka, M., Lazar, Z., Dulermo, T., Fickers, P., \& Nicaud, J.M. (2015). Lipid production by the oleaginous yeast Yarrowia lipolytica using industrial by-products under different culture conditions. Biotechnology for Biofuels, 8(1), 1-10. https://dx.doi.org/10.1186\%2Fs13068-015-0286-Z

Radha, P., Narayanan, S., Chaudhuri, A., Anjum, S., Thomas, D.L., Pandey, R., \& Ramani, K. (2020). Synthesis of single-cell oil by Yarrowia lipolytica MTCC 9520 utilizing slaughterhouse lipid waste for biodiesel production. Biomass Conversion and Biorefinery, 1-12. https://doi.org/10.1007/s13399-020-01132-y

Sara, M., Brar, S.K., \& Blais, J.F. (2016). Lipid production by Yarrowia lipolytica grown on biodiesel-derived crude glycerol: optimization of growth parameters and their effects on the fermentation efficiency. RSC advances, 6(93), 90547-90558. https://doi.org/10.1039/C6RA16382C

Santek, M.I., Beluhan, S., \& Santek, B. (2018). Production of microbial lipids from lignocellulosic biomass. In Advances in Biofuels Bioenergy, Edited by Nageswara-Rao, $M$ \& Soneji, J; InTechOpen: London, UK. http://dx.doi.org/10.5772/intechopen.74013

Sriwongchai, S., Pokethitiyook, P., Kruatrachue, M., Bajwa, P.K., \& Lee, H. (2013). Screening of selected oleaginous yeasts for lipid production from glycerol and some factors which affect lipid production by Yarrowia lipolytica strains. Journal of Microbiology, Biotechnology and Food Sciences, 2, 2344-2348.

Swiatkiewicz, S., \& Koreleski, J. (2009). Effect of crude glycerin level in the diet of laying hens on egg performance and nutrient utilization. Poultry Science, 88, 615-619. https:// doi.org/10.3382/ps.2008-00303
Taskin, M., Saghafian, A., Aydogan, M.N., \& Arslan, N.P. (2015). Microbial lipid production by cold-adapted oleaginous yeast Yarrowia lipolytica B9 in non-sterile whey medium. Biofuels, Bioproducts and Biorefining, 9(5), 595-605. https://doi.org/10.1002/bbb.1560

Taskin, M., Ortucu, S., Aydogan, M.N., \& Arslan, N.P. (2016). Lipid production from sugar beet molasses under non-aseptic culture conditions using the oleaginous yeast Rhodotorula glutinis TR29. $\begin{array}{llr}\text { Renewable Energy, 99, 198-204. } & \end{array}$ https:// doi.org/10.1016/j.renene.2016.06.060

Tasselli, G., Filippucci, S., Borsella, E., D'Antonio, S., Gelosia, M., Cavalaglio, G., ... \& Buzzini, P. (2018). Yeast lipids from cardoon stalks, stranded driftwood and olive tree pruning residues as possible extra sources of oils for producing biofuels and biochemicals. Biotechnology for Biofuels, 11(1), 1-16. https:/ / doi.org/10.1186/s13068-018-1142-8

Tchakouteu, S.S., Kopsahelis, N., Chatzifragkou, A., Kalantzi, O., Stoforos, N.G., Koutinas, A.A., ... \& Papanikolaou, S. (2017). Rhodosporidium toruloides cultivated in $\mathrm{NaCl}$-enriched glucose-based media: Adaptation dynamics and lipid production. Engineering in Life Sciences, 17(3), 237248. https://doi.org/10.1002/elsc.201500125

Uprety, B.K., Dalli, S.S., \& Rakshit, S.K. (2017). Bioconversion of crude glycerol to microbial lipid using a robust oleaginous yeast Rhodosporidium toruloides ATCC 10788 capable of growing in the presence of impurities. Energy Conversion and Management, 135, 117-128. https://doi.org/10.1016/j.enconman.2016.12.071

Wang, Y., Zhang, S., Zhu, Z., Shen, H., Lin, X., Jin, X., ... \& Zhao, Z.K. (2018). Systems analysis of phosphate-limitation-induced lipid accumulation by the oleaginous yeast Rhodosporidium toruloides. Biotechnology for Biofuels, 11(1), 1-15.

Yang, F., Hanna, M.A., \& Sun, R. (2012). Value-added uses for curde glycerol-a by product of biodiesel production. Biotechnology for Biofuels, $5,13$.

Zhang, S., Jagtap, S.S., Deewan, A., \& Rao, C.V. (2019). pH selectively regulates citric acid and lipid production in Yarrowia lipolytica W29 during nitrogen-limited growth on glucose. Journal of Biotechnology, 290, 10-15. https://doi.org/10.1016/j.jbiotec.2018.10.012 